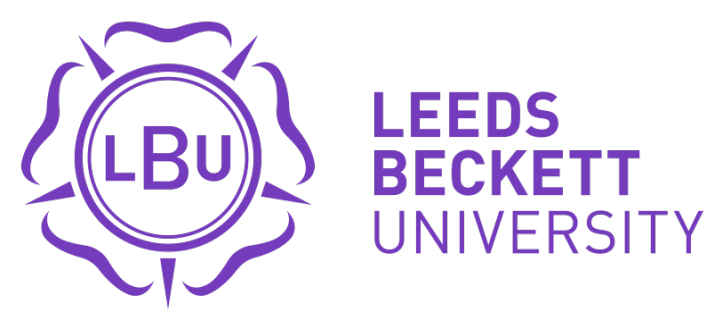

Citation:

Diers-Lawson, A and Coope, $\mathrm{K}$ and Tench, $\mathrm{R}$ (2020) Why can CSR seem like putting lipstick on a pig? Evaluating CSR authenticity by comparing practitioner and consumer perspectives. Journal of Global Responsibility. ISSN 2041-2568 DOI: https://doi.org/10.1108/JGR-02-2020-0033 (In Press)

Link to Leeds Beckett Repository record:

http://eprints.leedsbeckett.ac.uk/6668/

Document Version:

Article

The aim of the Leeds Beckett Repository is to provide open access to our research, as required by funder policies and permitted by publishers and copyright law.

The Leeds Beckett repository holds a wide range of publications, each of which has been checked for copyright and the relevant embargo period has been applied by the Research Services team.

We operate on a standard take-down policy. If you are the author or publisher of an output and you would like it removed from the repository, please contact us and we will investigate on a case-by-case basis.

Each thesis in the repository has been cleared where necessary by the author for third party copyright. If you would like a thesis to be removed from the repository or believe there is an issue with copyright, please contact us on openaccess@leedsbeckett.ac.uk and we will investigate on a case-by-case basis. 


\title{
Why can CSR seem like putting lipstick on a pig? Evaluating CSR authenticity by comparing practitioner and consumer perspectives
}

\author{
Audra Diers-Lawson \\ audra.lawson@leedsbeckett.ac.uk \\ Kerry Coope \\ AO.com \\ Ralph Tench \\ Leeds Beckett University, Leeds UK
}

\begin{abstract}
Purpose: The aim of this paper is to explain and better understand some of the challenges and even contradictions in relationships between CSR and stakeholder attitudes by comparing consumer and practitioner perspectives on social responsibility, its role in organisations, and its influence on consumer attitudes towards companies. Our objective is to understand and evaluate factors influencing the authenticity of social responsibility as a contributor to an organisation's value proposition.

Design/Methodology/Approach: Focus groups of consumers and practitioners $(\mathrm{N}=39)$ were asked to explore CSR in a semi-structured discussion. Themes were analysed using a constant comparative method.

Findings: These data suggest that rather than existing on a continuum of authenticity, there are clear paths emerging for CSR efforts to be deemed authentic versus inauthentic that can begin to better explain the often-contradictory findings with regard to consumer attitudes towards CSR and an organisation's value proposition. Consumer efficacy to influence an organisation and localised CSR emerge as critical determinants for evaluations of CSR as authentic. Further, these data also suggest practitioners may not understand consumer motivations and attitudes about CSR.

Practical Implications: Ultimately, these data produce testable models for authentic (i.e., motivator) and inauthentic (hygiene) consumer judgments about CSR and draw implications for CSR leadership, learning, and management.

Originality/ Value: These data provide new insights into evaluations of CSR to explain when and why it can fail to meet its objectives.

Keywords: CSR, Hygiene Motivation Theory, authenticity, consumer attitudes
\end{abstract}

Suggested reference:

Diers-Lawson, A., Coope, K., \& Tench, R. (in press). Why can CSR seem like putting lipstick on a pig? Evaluating CSR authenticity by comparing practitioner and consumer perspectives. Journal of Global Responsibility. doi:10.1108/JGR-02-2020-0033 
Why can CSR seem like putting lipstick on a pig?

Organisations are increasingly expected to be socially responsible with active corporate social responsibility (CSR) programmes (Tench, Sun, and Jones, 2014). Business cases for CSR argue it creates value by enhancing a business's integrative capacity by focusing on the interrelationships between shareholders, stakeholders, and society (Graafland \& Smid, 2019; Kurucz, Colbert, and Wheeler, 2008). Unfortunately, the direct relationship between CSR and the performance of a firm is tenuous at best with limited findings directly linking to financial performance (Barnett, 2019; Lee and Yoon, 2018; Saeidi, Sofian, Saeidi, Saeidi, and Saaeidi, 2015). At the very least, CSR was always thought to buffer organisations from crises with findings suggesting that social responsibility was strongly linked with a more positive precrisis reputation that helped to mitigate some of the negative effects of crises on organisations (Bae, Choi, and Lim, 2020; Kim, 2013). However, even the positive benefit of CSR in the context of reputational buffering is also being questioned (Coombs and Holladay, 2015).

In the context of the impact that CSR has on reputation, we focus on the public relations or stakeholder relationship management function of CSR. A stakeholder-based approach to CSR identifies legitimate and mutual values and causes that benefit both stakeholders' interest but also those that are mission-relevant for the organisation as a starting point for social responsibility (Cornelissen, 2014). Freeman, Wicks and Parmar (2004) explain the stakeholder model is an integral part to managing a business effectively because it focuses on shared values and mutual interests. It also acknowledges both internal and external stakeholders recommending that all CSR activities should consider the mutual desires of both stakeholders to direct the programme correctly (Brusseau, 2011; Magee, 2018).

Although CSR initiatives are commonly adopted in organisations with the assumption these initiatives will generate positive stakeholder outcomes like creating value and appeal with stakeholders (Habib and Hasan, 2019; Morgeson, et al., 2013), this objective is not without its challenges (Barnett, 2019; Blowfield and Murray, 2011; Erdiaw-Kwasie, 2018). Given that alternative and competing versions of an organisation's identity that may exist, stakeholders often question the sincerity of the CSR initiatives, viewing the actions as merely an effort to improve the company's reputation (Abraham, et al., 2018; Ahmad, et al., 2020; Cornelissen, 2014; Windsor, 2001). Additionally, CSR is often criticised because there is a lack of causal connection between CSR programmes and directly improving business performance (e.g., sales) (Barnett, 2007; 2019). Despite these limitations or criticisms, in recent years CSR has demonstrated reputational returns and improved stakeholder relationship management (Arevalo and Aravind, 2017; Bae, et al., 2020; Margolis, et al., 2003).

As such, the purpose of the present study is to try "reveal CSR as a fluid and discursive" concept that allows us to distinguish between different stakeholder perspectives and thus move away from functionalist analyses that seek overly simplified summaries the impact of CSR programmes (Crane and Glozer, 2016, p. 1244). In so doing we try to account for some of the challenges and even contradictions in relationships between CSR and stakeholder attitudes by comparing consumer and practitioner perspectives on social responsibility, its role in organisations, and its influence on consumer attitudes towards companies. Our objective is to understand and evaluate factors influencing the authenticity and persuasiveness of social responsibility as a contributor to an organisation's value proposition in order to better develop leadership and learning around social responsibility. 


\section{Literature Review}

If a primary objective for CSR programmes is to help manage and improve the relationships between organisations and stakeholders, then it is logical to begin by asking what benefits and drawbacks a CSR programme might have on this relationship. The pressure for active CSR initiatives is ever increasing (Arikan and Güner, 2013; Erdiaw-Kwasie, 2018) and it is being driven from a multitude of sources, including consumers' interests, fiercer competition, fear of scrutiny in the media and a growing number of employees/potential recruits wanting to be associated with a good company (Lacey, Kennett-Hensel, and Manolis, 2014; Manimegalai and Baral, 2018). However, just because an organisation has implemented a CSR programme or does CSR-related activities does not guarantee it will lead to positive outcomes (Einwiller and Carroll, 2020). CSR-related outcomes rely on several factors including the quality of the activity, the business case for it, and effectiveness of the communication surrounding the CSR initiatives (Barnett, 2019; Blowfield and Murray, 2011; Einwiller and Carroll, 2020).

Positive CSR-related outcomes for organisations. The most consistently documented positive outcome for CSR is reputation. Social responsibility initiatives have been linked to associations with an organisation's values, enhancing consumer loyalty, attracting better employees, and even attracting capital resources (Ahmad, et al., 2020; Islam, et al., 2016; Lee and Yoon, 2018; Lii and Lee, 2011; Manimegalai and Baral, 2018). Of course, these strongly relate to improving a company's business objectives (Blowfield and Murray, 2011; Du, et al., 2010). Additionally, CSR has been shown to improve consumer-company identification (CCI) as well (Aherne, Bhattacharya, and Gruen, 2005; Lii and Lee, 2011; Sen and Battacharya, 2003). Moreover, there are several other positive attitudinal or emotional outcomes demonstrated with successful CSR initiatives like high esteem, improved trustworthiness, brand loyalty, and positive word-of-mouth (pWOM) (Lii and Lee, 2011; Stanaland, Lwin, and Murphy 2011).

Lii and Lee's (2011) research also suggests that companies engaged in philanthropic activities were more successful at improving positive attitudinal and behavioural outcomes amongst their consumers than those organisations engaging in cause-related marketing and sponsorship activities. Therefore, organisations that have been the most successful with their CSR-related efforts have been the ones that demonstrate that social responsibility is an inherent part of their core business identity; that is, CSR is not merely some set of behaviours that represent the organisation being 'nice', but are those that are viewed as central to achieving business objectives (Blowfield and Murray, 2011; Du, Bhattacharya, and Sen 2010; Einwiller and Carroll, 2020; Erdiaw-Kwasie, 2018). In part, the extant research on social responsibility suggests that CSR activities should be relevant to the work the business does but not appear driven by profit motivation to improve stakeholder identification with the organisation, loyalty, and trust (Ahmad, et al., 2020; Aravelo and Aravind, 2017; Mohr, Webb, and Harris, 2001; Stanaland, et al., 2011).

Negative CSR-related outcomes for organisations. Given these conditions, it is possible that organisations could damage their relationships with their stakeholders if CSRinitiatives go badly, which may account for significantly lower levels of negative corporate social reporting (Einwiller and Carroll, 2020). Our discussion above provides a good starting point to identifying what can run amuck, but research suggest it could also have negative effects (Abraham, et al., 2018; Du, et al., 2010). For example, Forehand and Grier (2003) found that consumers do not respond negatively to CSR with extrinsic motives (e.g., companies want to better society and financially benefit from it), but do often respond negatively when they perceive obvious marketing efforts or programmes that ultimately 
benefit the company more than society. When companies fail to integrate social responsibility initiatives with business objectives, public relations becomes synonymous with lip service or more style than substance (Cornelissen, 2014; Lee and Yoon, 2018).

For example, the term greenwashing has emerged in recent years as more and more businesses have tried to frame themselves as environmentally friendly, when their core business model is anything but environmentally friendly (Cornelissen, 2014). Organisations enacting environmentally friendly programmes often face an uphill battle to look sincere even if their environmental social responsibility objectives are a part of their business model and core social agenda (Conrad, 2007). These data suggest that a potential challenge with CSR initiatives could come from a lack of understanding of the benefits of CSR programmes or even a complete miscommunication about how social responsibility is directly connected with a company's objectives (Mohr, et al., 2001).

\section{Motivation Hygiene Theory}

The findings and challenges for CSR suggest that a critical disconnect between CSR activities and how stakeholder interpret them is based on perceptions of the organisation's sincerity. As such, motivation hygiene theory provides a useful heuristic for explaining stakeholder reactions to CSR activities because it focuses on perceptions of motivation, thus providing a tool for better understanding consumer and practitioner perspectives on social responsibility because it allows us to focus on the notion of 'authenticity' - or the stakeholder judgment that CSR activities are directly linked to an organisation's values. Originally conceptualised by Herzberg (1959) as dual-factor theory, motivation-hygiene theory (MHT) originated as a human resources concept to help understand and explain employee satisfaction and dissatisfaction for managers and their workforces (Lacey, et al., 2014; Sachau, 2007). In the context of CSR and stakeholder relationship management, MHT suggests that social responsibility initiatives will be more successful when they invoke more intrinsic motivational factors, like meeting consumers' values, morals, desires, and demands in order to improve consumer-company identification (Herzberg, 1959; Lacey, et al, 2014; Magee, 2018).

Alternatively, hygiene factors are often more related to extrinsic functional needs (Holbrook, 1999). Simply put, if consumers believe that an organisation is acting socially responsible to encourage consumers to engage with them, use their product or services, then these will be viewed as hygienically motivated (i.e., an effort to look nicer or putting lipstick on a pig) (Lacey et al, 2014). This means that motivation and hygiene evaluations are likely not opposite ends of the same spectrum; rather lead to divergent paths of stakeholder satisfaction and dissatisfaction with the organisation (Lacey, et al., 2014; Vargo, et al., 2007). MHT can account for some of the challenging dialectics emerging from the positive and negative outcomes for CSR in recent years. Because social responsibility has become a social expectation in many industries, the absence of a specific CSR programme can lead to dissatisfaction with consumers (Cone, 2013; Lacey, et al., 2014), but the presence of a CSR programme may not necessarily create enough satisfaction to lead to the positive outcomes associated with it (Barnett, 2019; Erdiaw-Kwasie, 2018; Mohr, et al., 2001) and may even jeopardise the relationship between the organisation and its critical stakeholders (Abraham, et al., 2018). Yet both Mohr, et al. (2001) and Lacey, et al. (2014) argue there are fundamental gaps in our understanding of the relationships between social responsibility initiatives and consumer attitudes that cannot be accounted for with the traditional statistical data on consumer attitudes and behavioural intention with regard to CSR. Therefore, this study will tackle this problem by comparing consumer and practitioner perspectives to identify any lack 
of fit between perceptions of motivations by both sides of the organisation/ stakeholder relationship. As such, this paper seeks to answer the following research questions:

Research Question 1: What factors influence the evaluation of companies engaging in CSR as authentic or sincere?

Research Question 2: Are the factors influencing the evaluation of companies engaging in CSR as authentic the same as those influencing evaluations of CSR as inauthentic?

\section{Research Question 3: Are there differences in the perceptions of CSR by practitioners versus consumers?}

\section{Methodology}

This study adopts an interpretivist approach to better understand both consumers and public relations practitioners as social actors (Saunders and Lewis, 2012; Zavali and Theodoropoulou, 2018). A semi-structured focus-group interview methodology was employed using a purposive heterogeneous sampling method to focus on those participants who would be able to provide intelligence on the consumer and practitioner perspectives with as homogeneous of a sample as possible within each of the groups included (Daymon and Holloway, 2011; Saunders and Lewis, 2012).

\section{Data Collection}

For this study, participants were selected and broken down initially into two groups; practitioner-related (i.e., corporate communications or public relations professionals) and consumer. This resulted in 39 British participants participating across the six focus group discussions (two practitioner, $\mathrm{N}=13$ and four consumer, $\mathrm{N}=26$ ). Practitioners ranged in experience between 2 and 23 years of experience with both agency and in-house environments represented and an average of 7.38 years experience. The first practitioner group focused their discussion of social responsibility on differences between middle class and working-class consumers. As such, the consumers included in this study self-identified as 'working class' Northern English participants with 12 men and 14 women participating ranged in age from 20-67 years old. This decision was made both to improve the homogeneity of each of the groups investigated and to provide a clear juxtaposition between practitioner and consumer attitudes for the purpose of theory building.

Focus groups occurred in two waves. In wave one there was one practitioner group and two consumer groups. Additional groups were added to the point of saturation where no meaningful new themes emerged from the discussions creating an appropriate sample size for qualitative sampling (Abraham, et al., 2018; Daymon and Holloway, 2011).

Within all focus groups conducted for this research, a selection of four well-known British companies were used as a starting point for discussions of what participants felt about social responsibility and what makes companies 'good' or 'bad' in their view - the order of the companies was varied across the different focus groups to minimise primacy and recency effects in the discussion. Participants discussed their evaluations of each company and then information about each company's social responsibility initiatives was introduced and participant reactions to those specific initiatives and discussion about the degree to which those programmes affected their impression of the companies was used as a starting point for the deeper conversation about social responsibility. These four British businesses were screened ahead of time as being known to all participants, were used as discussion points, to highlight consumers' awareness, their attitudes and opinions on CSR programmes. The 
companies discussed were Primark, Gregg's, Tesco, and Nando's because they are familiar to British audiences.

There was not a set schedule of questions; rather, a focus on critical themes to explore including: how participants define 'corporate social responsibility', factors influencing CSR authenticity judgments, expectations of companies, the degree to which CSR influences their own purchasing decisions, and participant communication preferences about CSR initiatives. This enabled the conversation to flow effectively rather than having a highly scheduled set of questions that reduced discussion opportunities.

\section{Data Analysis}

Focus group interviews were transcribed and data analysed from a grounded theory perspective employing Strauss and Corbin's (1990) constant comparative method approach to analysing the data with a focus on coding the data throughout (Morse and Richards, 2002). This method focuses on analysing data using three coding processes together: (1) open coding by identifying critical themes emerging from each focus group as a way to compare, conceptualise, and categorise the data; (2) axial coding to interrogate the conditions, context, and interaction of attitudes emerging within the categories; and (3) selective coding to identify the most important categories and systematically relate them to previous research and other categories in order to validate the findings. The constant comparison method of data analysis allows for an emergent and theoretically grounded understanding of the phenomena to develop in order to contribute to theory development (RWJF, 2008). A second coder analysed $10 \%$ of the sample to establish intercoder reliability identifying an acceptable $73 \%$ agreement in open coding categories emerging from the data, $84 \%$ agreement in axial coding, and $77 \%$ agreement in selective coding.

\section{Results and Discussion}

When it comes to corporate social responsibility, these data suggest Northern English working class consumers are cynical. Focusing on value alignment as a way of understanding evaluations of authenticity judgements of CSR, these data provide insight into the factors influencing both authentic and inauthentic evaluations of social responsibility, identifying these are different processes, and that there are fundamentally different attitudes that consumers and practitioners often have regarding social responsibility. Finally, across the three stages of coding 11 distinctive themes with 22 CSR-specific attitudes emerged.

\section{Motivation and Hygiene Evaluations of CSR}

Table 1 provides a summary of the key themes and attitudes with representative examples from the focus group discussions. These data provide insight into the challenged nature of social responsibility revealing conditions when CSR activities may be evaluated as motivator and/or hygiene factors.

These data suggest that both consumers and practitioners distrust CSR programmes by organisations with poor reputations supporting and extending Manimegalai and Baral's (2018) findings that trust was a mediating role between CSR and job outcomes for employees to external stakeholders as well. This finding confirms previous research indicating when a company's CSR activities and their reputation were congruous, CSR leads to positive outcomes; however, where there was incongruity between reputation and CSR activities it led to higher levels of scepticism (Abraham, et al., 2018; Erdiaw-Kwasie, 2018; Kim and Lee, 2015). 


\section{Table 1}

\section{Key Themes and Attitudes Emerging}

\begin{tabular}{lll}
\hline \multicolumn{1}{c}{ Theme } & \multicolumn{1}{c}{ Attitude } & Participant Example(s) \\
\hline $\begin{array}{l}\text { Practitioner } \\
\text { Assumptions }\end{array}$ & $\begin{array}{l}\text { Lower SES consumers don't know, } \\
\text { don't care about CSR }\end{array}$ & $\begin{array}{l}\text { Practitioner: Primark probably don't really care much } \\
\text { about their footprint and promoting ethical behaviours } \\
\text { because a lot of their people who shop there aren't even } \\
\text { considering the elements of ethicality where it comes from. }\end{array}$ \\
& $\begin{array}{l}\text { Practitioner: The average Nando's consumer doesn't } \\
\text { care - people don't really know anything about Nando's at } \\
\text { all. }\end{array}$ \\
& $\begin{array}{l}\text { Practitioner: If you were speaking to average consumers } \\
\text { who don't work in marketing or comms. They perhaps } \\
\text { would go, 'oh that's interesting. I probably would think } \\
\text { about going to Nando's more.' }\end{array}$
\end{tabular}

Caring about employees is just good business practice

CSR Awareness \& Behavioural Intention

Cynicism About CSR
Even if I know about CSR, it doesn't change behavioural intention

Companies should just be socially responsible

CSR is not about doing good, it is about business objectives

CSR is a promotional gimmick
Practitioner: Without being really cynical, they sound like a brilliant company to work for, but also a lot of those things are just good business practise.

Consumer: It doesn't make a difference to me. It's very good that they do that $\langle\mathrm{CSR}>$ and it's great. More companies probably should, but it doesn't make me think I'm going to buy something from Gregg's because of that I still don't like them.

Practitioner: I definitely like companies when I know they're more environmentally friendly but it doesn't necessarily mean that l'll shop there or eat there or whatever, if I like that shop l'll go, and it's just like in some ways it's bad but it's how it is.

Consumer: It is part of being an internationally famous brand. It is your responsibility to give back to your roots and your community... but you don't have to go and scream and shout about it. Like, I give back to the kids at school, but I don't go shouting about it because that's my job.

Practitioner: No one wants to invest unless you can prove it - we have to show that we're gonna focus on sustainability and our CSR programme because it is so essential - not just to the business but to stakeholders and investors. Primark might not have it at their core, but they will absolutely have to focus on improving their footprint because otherwise they'll die out won't they, surely?

Consumer: I think it's a thing were a company will say, 'we've done it for the environment'. Well, no, you've done it because it's probably cheaper for you to do that, but they'll say it's for the environment.

Practitioner: I can't believe any successful company will do something for the ethical reasons first if it's gonna cost them money. You find both - trial and error - and y ou find both where yeah you may take a bit of a short-term hit, but you do it for the right reasons and to make money, which is fair enough

Consumer: We know that really they just want customers to come and shop there.

Practitioner: It c a bit tenuous, like we've bit a big shiny check for your charity and cause...that's a way of doing it badly, but if it's part of your ethos as a whole, then you should talk about it. 
Table 1 (continued)

\begin{tabular}{lll}
\hline \multicolumn{1}{c}{ Theme } & Attitude & Participant Example(s) \\
\hline $\begin{array}{l}\text { Cynicism about CSR } \\
\text { (continued) }\end{array}$ & $\begin{array}{l}\text { Distrust in CSR because of poor } \\
\text { reputation }\end{array}$ & $\begin{array}{l}\text { Consumer: I think they }<\text { Tescos do it to make the } \\
\text { company look good because they are losing money, so } \\
\text { they've had to start thinking outside the box, doing stuff in } \\
\text { the community with the food and the surplus, but they've } \\
\end{array}$ \\
& $\begin{array}{l}\text { made it so everyone knows about it. They've advertised } \\
\text { about it so it makes them look like a good company, so if } \\
\text { they look like a good company, they'll make a bigger profit. }\end{array}$
\end{tabular}

Practitioner: I'm inherently distrustful about what I'm being told, so when I see a nice two-minute video but everything in it has been particularly worded in a specific way.

Communicating CSR- Consumers want to know how Related Information organisations are socially responsible

Authentic communication matters for consumers

Social media influences CSR-related attitudes

CSR \& Agenda Setting

CSR \& $\ldots$

Employees A company is 'good if it cares for its employees
Consumer: I wanna be told this stuff. I think you just respect the company more for what they're doing for the community and their workers and stuff.

Consumer: I think that information should be available if you want it and are fussed.

Consumer: If we don't know about it $\langle$ CSR $>$, you just think they're as bad as every other company and actually they might not be. It's a fine line isn't it, they come on their advert and say, 'we're doing all this charity' but then you might say, 'oh right, why are you telling us all that - just to make us go and buy your pasties?'

Practitioner: I think it feels more genuine when they don't need to tell us <through advertising > because it's working for them, they're doing it because they want to help those communities and they don't need to tell us and everyone about it.

Consumer: It's like social media has a big impact on whether you think a company is good or bad or not. If it's not on social media, you probably don't know too much about it.

Consumer: So much travels by word-of-mouth so if those things were being put out on social media, it'll get passed around and people would be like, 'Yeah, I'm gonna go now because I know that'

Practitioner: They're just consuming it <information > in different formats, but only when someone's shared an article from somewhere else.

Consumer: Good things are left unsaid, like none of us knew how good Gregg's are with stuff like that, but obviously when it's something bad, the media just shines a light on it.

Practitioner: I do think what a lot of people think about companies is probably largely influenced by what they see in the press and the press never cover good news.

Consumer: Richard Branson does it with his workers, like one of his main quotes is like, "if you look after your staff well, your staff will look after your customers even better' and as far as I'm aware, he looks after his staff really well, like they get well-paid and well-treated

Practitioner: I often think about lower skilled, I don't know if that's the correct term, but companies that do have those roles should really do more to try and help like with rehabilitation back into society for people who struggle. 
Table 1 (Continued)

\begin{tabular}{|c|c|}
\hline Theme & Attitude \\
\hline$R$ \&.. & \\
\hline Employees & $\begin{array}{l}\text { Geography of employee-related CSR } \\
\text { matters }\end{array}$ \\
\hline
\end{tabular}
matters

Worker exploitation is a part of getting

Authenticity

CSR programmes should be on-going because of corporate values

Efficacy Inability to affect change

CSR vs ...

Personal Ethics When products are in demand or trendy, personal ethics does not matter much

Convenience

Life's too busy to care about CSR

Consumers care about issues they can control inexpensive goods

Consumer: $<$ When the employees are a long ways away and mistreated $>$... it's out of sight, out of mind at the moment. You don't think about it because it's not happening anywhere where it affects you or yours, so it doesn't matter.

Consumer: If you have a mate that worked in a factory if it was here and they was telling you, 'I'm getting treated so bad, I'm paid nothing, working conditions are so unsafe' you'd be more likely well 'I'm not shopping there, but because it's not people you know and care about it doesn't affect you.'

Consumer: I think the exploitation and how people are treated matters. I mean it runs from all the way from employees that work in shops here, all the way to where the products actually come from and I think you just know there's a lot of exploitation and the way people are treated is bad...you can't buy a jacket for $£ 15$ and not be like, 'well how the hell is it so cheap'

Practitioner: How can you make something this cheap and pay someone a decent living wage?

Consumer: I think with companies, if you're gonna have an ethos like that, it has to come from the top.

Practitioner: If you just look like the man with the big cheque, you don't look genuine.

Practitioner: I like the Body Shop, they don't test on animals, but every so often it's like $50 \%$ of stuff will go to certain charities and you can sign something and it'll tell you which charity it's going to as well, so that's nice.

Consumer: It's not enough impact on a personal level for you to make a change - like if I stop buying cans of Coca Cola, they're still gonna exploit water and nothing's gonna change...there's just not much I can see that can be done about it.

Practitioner: You're only in charge of your own actions.

Consumer: It's your responsibility in your four walls, and guess on your upbringing, we've been brought up to recycle and not waste water or electric, but you do and you back the buck to them <companies $>$

Practitioner: Yeah, it's their responsibility, just like in my home it's my own responsibility and no one else's.

Consumer: I go to Primark because I can get nice clothes that are on trend. Do I feel good about it? No, but I'm still going to shop there.

Practitioner: My point is, even though it <an expensive company $>$ is probably as unethical as Primark, it somehow feels more legitimate because it's an expensive product.

Consumer: When you were younger we used to go the fruit and veg shop, and butchers and supermarket, but like life's busy and so now it's just far easier to just go and buy it all under one roof, it's convenience and it appeals to a lot of people that they get everything they want from Tesco.

Consumer: We're lazy. We're lazy as a nation... we're a nation of convenience. 
Table 1 (continued)

\begin{tabular}{|c|c|c|}
\hline Theme & Attitude & Participant Example(s) \\
\hline \multirow[t]{3}{*}{ Price } & $\begin{array}{l}\text { Affordability is more important than } \\
\text { social responsibility }\end{array}$ & $\begin{array}{l}\text { Consumer: You're reliant on yourself as you get older, it's } \\
\text { your income, and so you have to live by your own means. } \\
\text { Practitioner: It comes down to affordability, and what you } \\
\text { are willing to sacrifice on your spending, you know like } \\
\text { generally everybody wants to eat of a certain quality I } \\
\text { would say, depending on what the quality is to you and } \\
\text { where you choose to shop }\end{array}$ \\
\hline & People just want to spend less & $\begin{array}{l}\text { Consumer: I really like Aldi and I don't know much about if } \\
\text { their stuff is locally sourced or anything. I feel like it is. But } \\
\text { the price is such an important factor, but I know it's good } \\
\text { quality even though it's so cheap. }\end{array}$ \\
\hline & & $\begin{array}{l}\text { Practitioner: End of the day, it's a convenience and price } \\
\text { thing, if you was all rich you'd all get expensive matching } \\
\text { pyjamas from Victoria's Secret, that's literally what it } \\
\text { comes down to with Primark. }\end{array}$ \\
\hline \multirow[t]{2}{*}{ Quality } & Quality matters more & $\begin{array}{l}\text { Consumer: If you don't like it, you won't go regardless of } \\
\text { what they do or don't do. }\end{array}$ \\
\hline & & $\begin{array}{l}\text { Practitioner: It's the quality as well. I don't think it's ever } \\
\text { about what they're doing. }\end{array}$ \\
\hline
\end{tabular}

CSR and motivational assessments. The cynicism present about CSR confirms that authenticity is a critical factor that enables CSR activities to be viewed as motivational and not merely hygiene oriented. However, these data suggest there are a number of factors that are more likely to persuade consumers that social responsibility initiatives are authentic.

Initially, authenticity was strongly connected to the ways in which consumers learned about a company's CSR activities. There was a strong negative attitude that CSR was often just a promotional gimmick with respondents saying things like, 'We know that really they just want customers to come and shop there.' However, there were also strong attitudes that consumers want to know what kinds of socially responsible activities organisations engage in. The challenge was that communication about CSR needed to feel natural or just a part of an organisation's routine work. These findings are aligned with previous research that suggests a corporate 'heritage' of social responsibility leads to more effective CSR communication (Balmer, Blombäck, and Scandelius, 2013; Aravelo and Araund, 2017; Erdiaw-Kwasie, 2018; Mohr, et al., 2001). Coupled with the findings from this study that social media discussion influences CSR-related attitudes amongst consumers, these data suggest that organisations that are able to create and activate strong brand communities online should find more positive results for CSR activities. These findings are supported by a critical evaluation of social media in a global context (Kesavan, Bernacchi, and Mascarenhas, 2013) as well as empirical research in China (Chu and Chen, 2017). More generally, these data also suggest that in a digital age, public relations - especially online - could play an important role in ensuring that CSR is viewed as intrinsic to a company's mission and vision (Moretti and Tuan, 2015).

Beyond issues of how CSR is communicated about, two other factors seem to strongly influence attitudes about the authenticity of an organisation's social responsibility. First is efficacy - the belief their actions as a consumer (i.e., offering or withholding custom) could affect a company influenced their interest in the company's CSR objectives. When consumers did not believe they could influence a company by offering or withholding custom, then they were less interested in CSR (see Table 1). Second, consumers were more 
likely to connect with CSR when they felt like the issues were ones they could affect. Thus, these data suggest that consumer empowerment may be important in improving the impact of CSR activities.

Additionally, the importance of a local connection to CSR was evident in discussions about the importance of employee-related social responsibility. In these discussions, participants acknowledged that worker exploitation seemed an inevitable part of getting inexpensive goods but also found it difficult to get passionate about worker rights for people who are thousands of miles away (see Table 1). However, employee CSR at the local level mattered a great deal for consumers, in particular, because they could imagine it affecting people they knew and thus they associated employee care at the local level with a company's motivation to be socially responsible. Taken together, the efficacy and employment attitudes reflect a potential critical factor in stakeholder attitudes- localized CSR activities can be a persuasive tool for organisations to be viewed as authentically socially responsible. This seems to be a relatively new perspective on CSR because while previous research has discussed global versus local CSR strategies, the questions about social responsibility tend to focus on whether multi-national corporations should allow for localized initiatives (Muller, 2006) or the link between CSR strategy and brand equity comparing local and global markets (Popoli, 2011). However, these data would suggest that local-level CSR is more instrumental in determining whether stakeholders will view the activities as authentic or not.

CSR and hygiene assessments. Overall, these data suggest that while participants would like organisations to be socially responsible, they are quick to dismiss CSR initiatives as hygiene-related behaviours, limiting the potential positive impact of resource commitment to CSR. Both consumers and practitioners expressed beliefs that social responsibility is not altruistic; that it is about achieving business objectives (see Table 1). In some ways, this perception may not be entirely problematic as previous research points to the new reality that businesses ought to be socially responsible (Abraham, et al., 2018; Arikan and Güner, 2013; Tench, et al., 2014). Likewise, other emergent themes and attitudes in the present research also confirm this attitude with regards to participant expectations that companies should be socially responsible employers; that CSR programmes should be ongoing, thus reflecting an organisation's values; and that consumers do want access to information about corporate social responsibility (see Table 1). Yet, participants also describe it cynically suggesting that companies only do it for convenience or self-serving ends. The cynicism about the sincerity of CSR activities confirms the duality discussed in MHT (Herzberg, 1959; Lacey, et al., 2014) indicating that when stakeholders believe CSR is motivated by hygiene interests, they do not necessarily evaluate the organisation negatively; rather, the positive outcomes are unlikely to be met.

\section{Limitations of CSR on Behavioural Intention}

Beyond the motivation and hygiene assessments that these data demonstrate, they also provide explanation as to why CSR may not always lead directly to changes in behavioural intention on the part of stakeholders as these data reveal conflicts of interest that a positive reputation or high rating of social responsibility are not likely to overcome. In particular, five factors emerge as potentially strong reasons why, despite positive or negative evaluations of a company's social responsibility profile may fail to influence purchase intention amongst consumers (see Table 1).

These data suggest that when products are in demand or trendy that consumers' personal ethics become less relevant. For example, Primark was consistently evaluated by respondents as being socially irresponsible; yet, participants also indicated this was not likely to deter them from shopping there (see Table 1). These findings demonstrate that not only are 
consumers probably aware when their own personal ethics are compromised but they make conscious decisions based on other factors.

Price, convenience, and quality were consistently identified by the participants as the three factors that were more likely to influence their purchase or shopping decisions if they conflicted with social responsibility values. Whereas much of the research on a company's values and CSR today focuses on social responsibility or sustainability as a core value, especially in a European context, (Acquier, Valiorgue, and Daudigeos, 2017; Baldassarre, Calabretta, Bocken, and Jaskiewicz, 2017; Kujala and Korhonen, 2017; O’Brien, Jarvis, Soutar, and Ouschan, 2018; Payne, Frow, and Eggert, 2017), yet the concept of customer value proposition, absent specific agendas (like CSR) remains understudied. Moreover, these findings also directly contradict Zavali and Theodoropoulou's (2018) research in Greece identifying that even after a financial crisis, consumers maintained their commitment to CSR. Thus, the extent to which cultural values versus pragmatic desires influence behavioural intention needs to be further investigated. One way to consider this, however, is by focusing on better understanding consumer value propositions because when CSR is connected to consumer values, it seems there is greater potential than when price, convenience, and quality are core value drivers (Lee and Yoon, 2018; Magee, 2018; Payne, Frow, and Eggert, 2017).

Finally, the influence of CSR may be limited when it comes to global organisations. As the discussion earlier suggested, when consumers' perception of their own response efficacy to influence organisations is limited, then these data suggest they are less willing to change their behaviours regarding CSR because they do not believe it will make a difference (see Table 1).

\section{The Impact of Practitioner and Consumer Divides on CSR Communication Strategy}

The final critical insights that we learned from these data point to some meaningful disconnections between practitioner attitudes towards consumers and CSR. These disconnections could provide explanation as to why communication strategies and even CSR activities might be viewed as motivation versus hygiene centred. There were three emergent assumptions about consumers - especially working class consumers - from practitioners: (1) when consumers express their interest in employee treatment, practitioners assume consumers are only talking about low-skill workers and not workers in general; (2) consumers, especially lower socio-economic status, do not know and probably do not care about CSR; and (3) practitioners seem to underestimate the power of social media and content creation because they talk about websites and traditional media outlets while consumers talk about social media and engagement surrounding communicating about corporate CSR activities (see Table 1).

Yet at the same time, these practitioners believed that they were more attuned to social responsibility than 'average consumers' simply because they work in communications. There seemed to be an arrogance communicated about consumers throughout the discussion by practitioners when it came to whether or not consumers consider the ethics of sourcing, CSR activities, or employment social responsibility. Yet, what these data reveal is clear consumer awareness about social responsibility, a self-reflexive understanding of the hypocrisy of their own consumption choices, but a different conceptualisation of what it means to be a 'good' company based on the global/local divide and their efficacy to affect the supply chain through their consumption choices.

Taking this level of disconnection into account this could offer an explanation as to why communication strategy concerning CSR communication may not be adequately addressing the mutual interests and needs of organisations and consumers thus relegating 
CSR towards mere hygiene. When we consider the findings from this study that point to the importance of authenticity in both CSR activities and communication strategy to promote those endeavours, it could help explain the divergent findings regarding CSR's outcomes.

\section{Conclusions}

The core findings from this study are consistent with previous research, but enrich our understanding of the conditions that improve the likelihood that CSR will produce desirable outcomes for organisations. Using MHT as our principle theory, these data reveal a testable model for evaluating the factors influencing authenticity judgments about CSR and its outcomes. These data suggest a positive relationship between a judgment of CSR activities as being authentic and consumer efficacy (both self and response), localised CSR impact, and organisational reputation (see Figure 1). Based on these data, an authentic CSR judgment will lead to improved behavioural intention and relational outcomes for organisations, so long as there is no conflict with the mediator variables (Baron and Kenny, 1986) of price, convenience, and quality. These data suggest that when price, convenience, and quality are in conflict with CSR activities, consumers are likely to disregard CSR and even their own personal ethics and make purchasing decisions with those priorities in mind. However, assuming the authenticity judgment for CSR is positive, it is still possible for organisations to improve their relationships with key consumer groups through CSR activities for long-term relationship management and crisis buffering objectives.

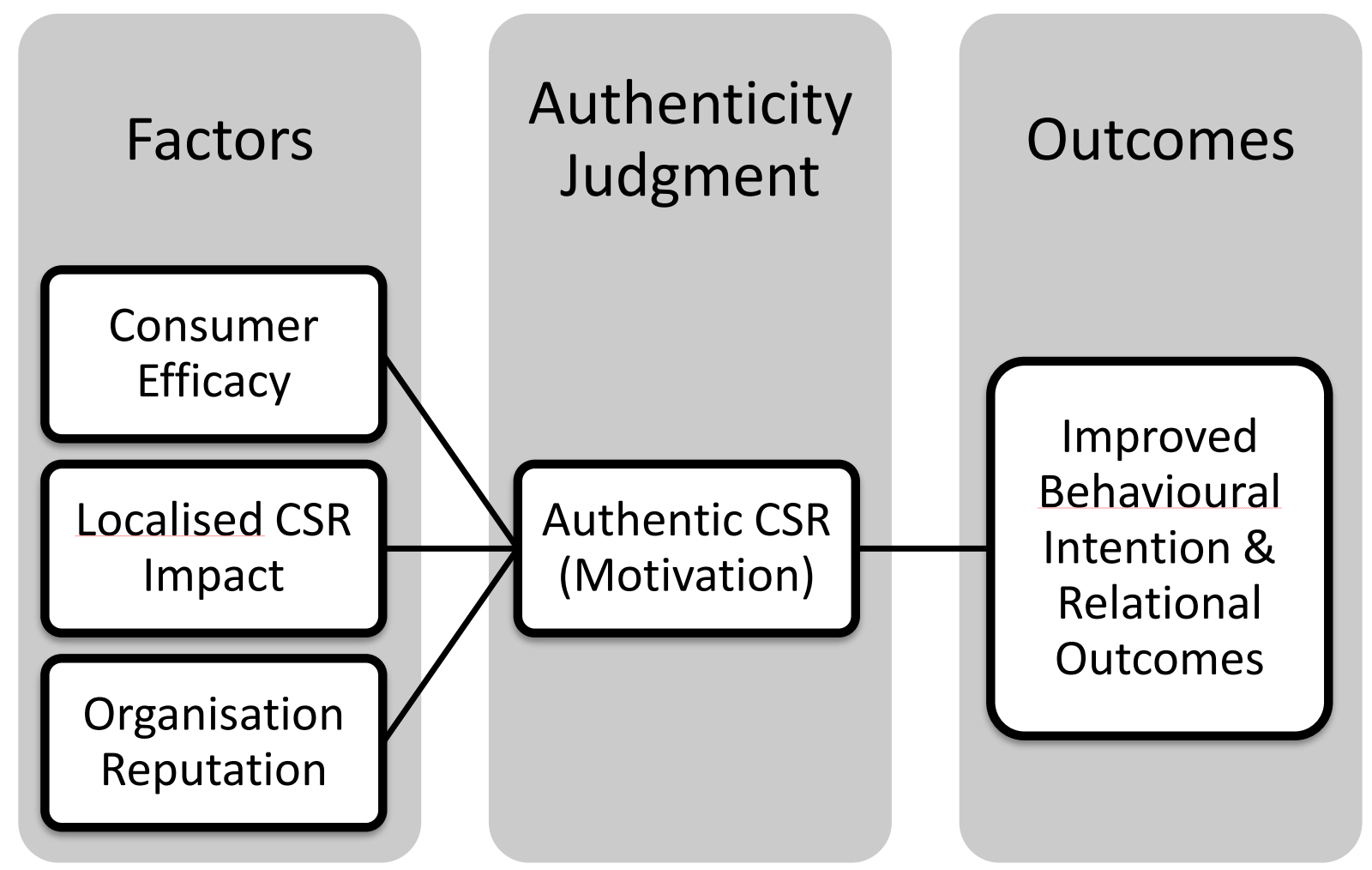

Figure 1. Model for Predicting the Outcomes of Authentic CSR 
These data also suggest that when consumers feel a lack of efficacy (self and/or response), when CSR activities are believed to be more 'global' in their impact, when the organisation has a bad reputation, or when the CSR activity is viewed as being done for promotional ends (i.e., consumers do not believe the activity is tied to the organisation's mission or core business objectives), then they are more likely to view the CSR activity(ies) as inauthentic (i.e., mere hygiene) (see Figure 2). When the authenticity judgment is negative, then that is likely to lead to unimproved behavioural intention and relational outcomes. There is no indication in these data as to how the mediators of price, convenience and quality in the authentic CSR model might affect outcomes in this hygiene model.

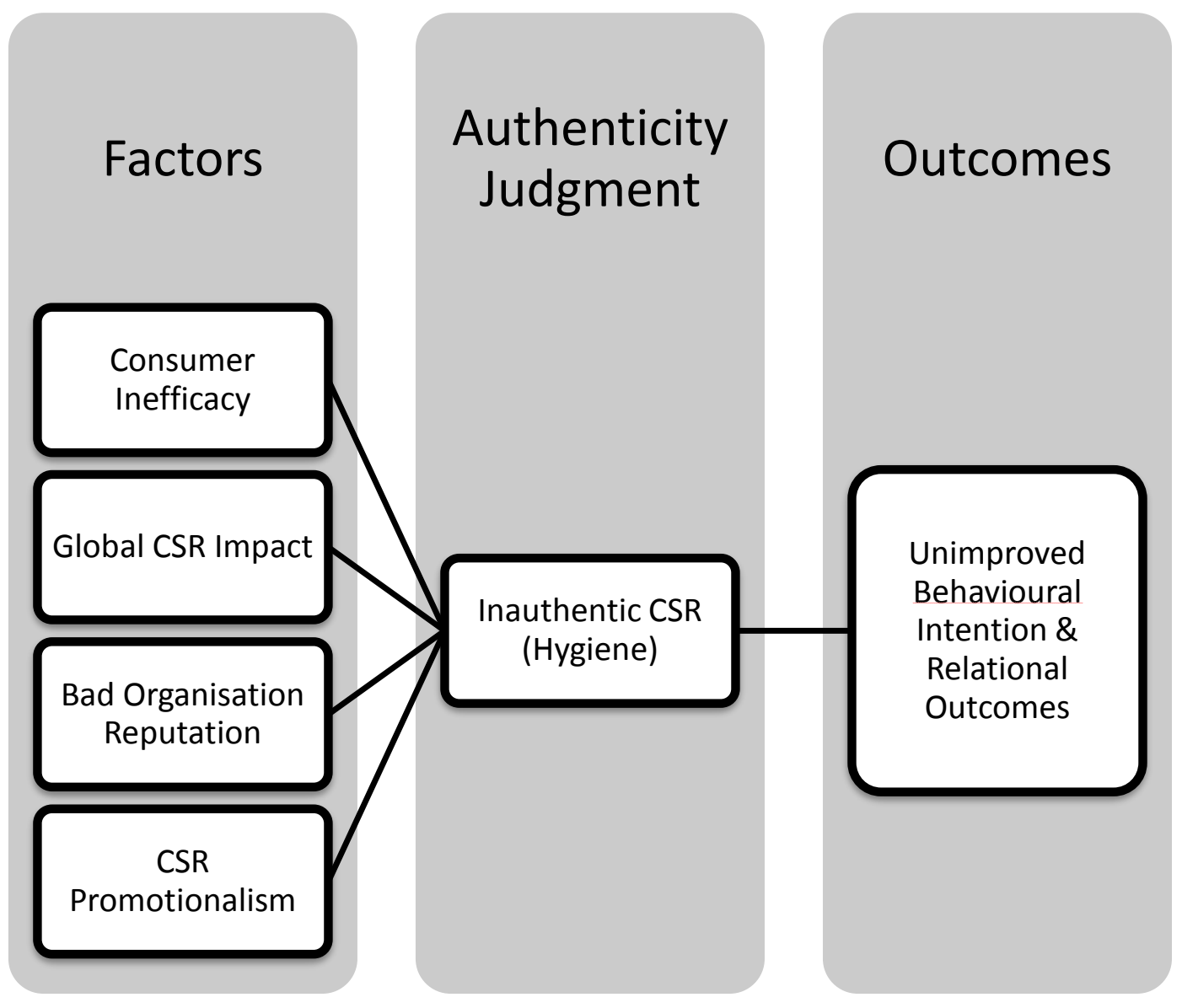

\section{Figure 2. Model for Predicting the Outcomes of Inauthentic CSR}

Though these data are unlikely to address all of the reasons that CSR may fail to meet its behavioural intention and relational objectives, we argue that these data do provide important intelligence that can be tested and further developed in future research. The factors identified in these data should also be tested outside of the United Kingdom to evaluate the applicability amongst non-British audiences as well. In an applied context, these data also suggest that practitioners must be rigorous in avoiding their own selective biases about CSR activities and consumers when designing communication strategies surrounding these activities. Finally, these data also suggest that there could be limited application of causerelated marketing and advocacy advertising strategies when communicating about CSR in order to ensure that the CSR activities are viewed as authentic and not merely hygiene; however, this conclusion should be more directly researched. Yet, these data do suggest that traditional public relations activities - especially online, with social media, and multi-media content creation - can be used to generate engagement and pWOM about an organisation's CSR programmes. 


\section{References}

Abraham, E. M., Asor, V., Torviawu, F., Yeboah, H. \& Laryea, F. (2018). Public perception of corporate social responsibility of AngloGold Ashanti in Obuasi Municipality, Ghana. Social Responsibility Journal, $14,485-500$.

Acquier, A., Valiorgue, B., \& Daudigeos, T. (2017). Sharing the shared value: A transaction cost perspective on strategic CSR policies in global value chains. Journal of Business Ethics, 144(1), 139-152.

Ahmad, R., Ahmad, S., Islam, T., \& Kaleem, A. (2020). The nexus of corporate social responsibility (CSR), affective commitment and organisational citizenship behaviour in academia: A model of trust. Employee Relations, 42(1), 232-247. doi:https://doi.org/10.1108/ER-04-2018-0105

Arevalo, J. A. \& Aravind, D. (2017). Strategic Outcomes in Voluntary CSR: Reporting Economic and Reputational Benefits in Principles-Based Initiatives. Journal of Business Ethics, 144 (1), 201 217.

Arıkan, E. \& Güner, S. (2013). The impact of corporate social responsibility, service quality and customer-company identification on customers. Procedia-Social and Behavioral Sciences, 99, pp.304-313.

Bae, J., Choi, W., \& Lim, J. (2020). Corporate social responsibility: An umbrella or a puddle on a rainy day? Evidence surrounding corporate financial misconduct. European Financial Management, 26(1), 77-117. doi:https://doi.org/10.1111/eufm.12235

Baldassarre, B., Calabretta, G., Bocken, N., \& Jaskiewicz, T. (2017). Bridging sustainable business model innovation and user-driven innovation: A process for sustainable value proposition design. Journal of Cleaner Production, 147, 175-186.

Balmer, J. M., Blombäck, A., \& Scandelius, C. (2013). Corporate heritage in CSR communication: a means to responsible brand image? Corporate Communications: An International Journal, 18(3), 362-382. doi:http://dx.doi.org/10.1108/CCIJ-072012-0048

Barnett, M. L. (2019). The business case for corporate social responsibility: A critique and an indirect path forward. Business \& Society, 58(1), 167-190.

Barnett, M. L. (2007). Stakeholder influence capacity and the variability of financial returns to corporate social responsibility. Academy of Management Review, 32 (3), 794-816.

Baron, R. M., \& Kenny, D. A. (1986). The moderator-mediator variable distinction in social psychological research: Conceptual, strategic, and statistical considerations. Journal of personality and social psychology, 51(6), 1173.

Blowfield, M., \& Murray, A. (2011). Corporate Responsibility. United States of America: Oxford University Press.

Brusseau, J. (2011). The Business Ethics Workshop. N/A: FlatWorld.

Conrad, D. (2007). More Corporate Greenwashing: Starbucks' Cups, Eco-Friend or Eco-Foe?. Available: https://www.organicconsumers.org/news/morecorporate-greenwashing-starbucks-cups-eco-friendor-eco-foe. Last accessed 3rd April 2018.

Chu, S. C., \& Chen, H. T. (2017). Corporate social responsibiliy (CSR) communication in social media in China: The role of identification with the company and brand trust. Paper presented at the American Academy of Advertising. Conference. Proceedings (Online).

Coombs, T., \& Holladay, S. (2015). CSR as crisis risk: expanding how we conceptualize the relationship. Corporate Communications: An International Journal, 20(2), 144-162. doi:http://dx.doi.org/10.1108/CCIJ-10-2013-0078

Cornellissen, J. (2014). Corporate Communication: A Guide to Theory and Practise. London: Sage Publications.

Crane, A., \& Glozer, S. (2016). Researching corporate social responsibility communication: Themes, opportunities and challenges. Journal of Management Studies, 53(7), 1223-1252.

Daymon, C. \& Holloway, I. (2011). Qualitative Research Methods in Public Relations and Marketing Communications. 2nd ed. Oxon: Routledge.

Du, S., Bhattacharya, C. B., \& Sen, S. (2010). Maximizing business returns to corporate social responsibility (CSR): The role of CSR communication. International journal of management reviews, 12(1), 8-19.

Einwiller, S. A., \& Carroll, C. E. (2020). Negative disclosures in corporate social responsibility reporting. Corporate Communications: An International Journal, aheadof-print(ahead-of-print). doi:https://doi.org/10.1108/CCIJ-05-2019-0054

Erdiaw-Kwasie, M. O. (2018). Does pressure-induced partnership really matter? Empirical modelling of stakeholder pressure and firms' CSR attitude. Social Responsibility Journal, 14, 685-698

Forehand, M. R \& Grier, S. (2003). When is honesty the best policy? The effect of stated company intent on consumer scepticism. Journal of Consumer Psychology, 13, 349-356.

Freeman, R. E., Wicks, A. C. \& Parmar, B. (2004). Stakeholder theory and "the corporate objective revisited”. Organization Science, 15(3), 364-369.

Graafland, J., \& Smid, H. (2019). Decoupling among CSR policies, programs, and impacts: An empirical study. Business \& Society, 58(2), 231-267.

Habib, A., \& Hasan, M. M. (2019). Corporate socia responsibility and cost stickiness. Business \& Society, 58(3), 453-492.

Herzberg, F. (1959). The motivation to work. New York: Holy Wiley \& Sons.

Holbrook, M. B. (1999). Consumer value: a framework for analysis and research. Psychology Press.

Islam, T., Ahmed, I., Ali, G., \& Sadiq, T. (2016). Behavioral and psychological consequences of corporate social responsibility: need of the time. Social Responsibility Journal, 12(2), 307-320. doi:https://doi.org/10.1108/SRJ-04-2015-0053

Kesavan, R., Bernacchi, M. D., \& Mascarenhas, O. A. (2013). Word of mouse: CSR communication and the social media. International Management Review, 9(1), 5866

Kim, H. S., \& Lee, S. Y. (2015). Testing the Buffering and Boomerang Effects of CSR Practices on Consumers' Perception of a Corporation during a Crisis. Corporate reputation review, 18(4), 277-293. doi:10.1057/crr.2015.18 
Kim, S. (2013). Corporate ability or virtue? Relative effectivenss of prior corporate associations in times of crisis. International Journal of Strategic Communication, 7(4), 241-256. doi:10.1080/1553118X.2013.824886

Kujala, J., \& Korhonen, A. (2017). Value-Creating Stakeholder Relationships in the Context of CSR Stakeholder Engagement: Clinical Research Cases (pp. 63-85): Springer.

Kurucz, E. C., Colbert, B. A., \& Wheeler, D. (2008). The business case for corporate social responsibility. In A. Crane, A. McWilliams, D. Matten, J. Moon, \& D. S. Siegel (Eds.), The Oxford handbook of corporate social responsibility (pp. 83-112). USA: Oxford University Press.

Lacey, R., Kennett-Hensel, P. A. \& Manolis, C. (2014). Is corporate social responsibility a motivator or hygiene factor? Insights into its bivalent nature. Journal of the Academy of Marketing Science, 43(3), pp.315332.

Lee, E.-M., \& Yoon, S.-J. (2018). The effect of customer citizenship in corporate social responsibility (CSR) activities on purchase intention: the important role of the CSR image. Social Responsibility Journal, 14(4), 753-763.

Lefebvre, R. C. (2000). Theories and models in social marketing. In P.N. Bloom \& GT Gundlach (Eds.), Handbook of Marketing and Society, Newbury Park, CA: Sage Publications.

Lii, Y. S. \& Lee, M. (2011). Doing Right Leads to Doing Well: When the Type of CSR and Reputation Interact to Affect Consumer Evaluations of the Firm. Journal of Business Ethics, 105(1), 69 - 81.

Magee, R. G. (2018). Environmental worldview beliefs and CSR advertising. Social Responsibility Journal.

Manimegalai, S. \& Baral, R. (2018). Examining the mediating role of organizational trust in the relationship between CSR practices and job outcomes. Social Responsibility Journal, 14, 433-447.

Margolis, J. D., \& Walsh, J. P. (2003). Misery loves companies: Rethinking social initiatives by business. Administrative Science Quarterly, 48, 268 -305.

Mohr, L., Webb, D. J. \& Harris, K. E. (2001). Do Consumers Expect Companies to be Socially Responsible? The Impact of Corporate Social Responsibility on Buying Behaviour. The Journal of Consumer Affairs, 35(1), $45-72$

Moretti, A., \& Tuan, A. (2015). The Social Media Manager as a Reputation's Gatekeeper: an Analysis from the New Institutional Theory Perspective. ISSN 2045-810X, 153.

Morgeson, F. P., Aguinis, H., Waldman, D. A., \& Siegel, D. S. (2013). Extending corporate social responsibility to the human resource management and organizational behavior domains: a look to the future. Personnel Psychology, 66(4), 805-824.

Morse, J. \& Richards, L. (2002). Read me first for a user's guide to qualitative research. CA, US: Sage Publications Thousand Oaks.
Muller, A. (2006). Global versus local CSR strategies. European Management Journal, 24(2-3), 189-198.

O’Brien, I. M., Jarvis, W., Soutar, G., \& Ouschan, R. (2018). Co-creating a CSR strategy with customers to deliver greater value Disciplining the Undisciplined? (pp. 89-107): Springer.

Payne, A., Frow, P., \& Eggert, A. (2017). The customer value proposition: evolution, development, and application in marketing. Journal of the Academy of Marketing Science, 45(4), 467-489.

Popoli, P. (2011). Linking CSR strategy and brand image: Different approaches in local and global markets. Marketing Theory, 11(4), 419-433.

RWJF. (N/A). Constant Comparative Method - Grounded Theory. Available: http://www.qualres.org/HomeCons-3824.html. Last accessed 10th March 2018.

Sachau, D. A. (2007). Resurrecting the Motivation-Hygiene Theory: Herzberg and the Positive Psychology Movement. Human Resources Development Review, 6(4), 377-393

Saeidi, S. P., Sofian, S., Saeidi, P., Saeidi, S. P., \& Saaeidi, S. A (2015). How does corporate social responsibility contribute to firm financial performance? The mediating role of competitive advantage, reputation, and customer satisfaction. Journal of Business Research, 68(2), 341-350.

Saunders, M. \& Lewis, P. (2012). Doing Research in Busines \& Management: And Essential Guide to Planning Your Project. Essex: Pearson Education Limited.

Sen, S., \& Bhattacharya, C. B. (2001). Does doing good always lead to doing better? Consumer reactions to corporate social responsibility. Journal of Marketing Research, $38,225-243$

Stanaland, A. J., Lwin, M. O., \& Murphy, P. E. (2011). Consumer perceptions of the antecedents and consequences of corporate social responsibility. Journal of Business Ethics, 102(1), pp.47-55.

Strauss, A. L., \& Corbin, J. M. (1990). Grounded Theory Methodology. In: Strauss, A.L. and Corbin, J.M Basics of Qualitative Research: Grounded Theory Procedures and Techniques. Michigan: Sage Publications. 273 - 285

Tench, R., Sun, W., \& Jones, B. (2014). Communicating corporate social responsibility: Perspectives and practice. Emerald Group Publishing.

Vargo, S. L., Nagao, K., He, Y. \& Morgan, F. W. (2007). Satisfiers, Dissatisfiers, criticals, and neutrals: A review of their relative effects on customer (dis) satisfaction. Academy of Marketing Science Review, 2007, 1 .

Waddock, S. E., \& Graves, S. B. (1997). The corporate social performance-financial performance link. Strategic Management Journal, 18, 303-319.

Zavali, M., \& Theodoropoulou, H. (2018). Investigating determinants of green consumption: evidence from Greece. Social Responsibility Journal, 14(4), 719736. 